\title{
Optimization of the production of mycorrhizal inoculum on substrate with organic fertilizer
}

\author{
Ieda R Coelho ${ }^{1}$, Maria VL Pedone-Bonfim ${ }^{1}$, Fábio SB Silva ${ }^{2}$, Leonor C Maia ${ }^{1 *}$ \\ ${ }^{1}$ Departamento de Micologia, Centro de Ciências Biológicas, Universidade Federal de Pernambuco, \\ Recife, PE, Brazil. \\ ${ }^{2}$ Programa de Pós-Graduação em Biologia Celular e Molecular Aplicada, \\ Instituto de Ciências Biológicas, Universidade de Pernambuco, Recife, PE, Brazil.
}

Submitted: October 9, 2012; Approved: June 6, 2014

\begin{abstract}
The system for production of inoculum of arbuscular mycorrhizal fungi (AMF) using sand and vermiculite irrigated with nutrient solution is promising. However, organic amendments added to the substrate can stimulate sporulation of AMF and replace the nutrient solution. The aim of this study was to maximize the production of AMF (Acaulospora longula, Claroideoglomus etunicatum, Dentiscutata heterogama and Gigaspora albida) using selected organic substrates (vermicompost, coir dust and Tropstrato) together with sand and vermiculite. The production of spores varied among the tested AMF and according to the organic source added to the substrate. The vermicompost promoted higher sporulation of $A$. longula in relation to the other AMF and substrates. The Tropstrato ${ }^{\circledR}$ inhibited the sporulation of $D$. heterogama while the reproduction of $C$. etunicatum was not affected by the organic compounds. The inoculum of $A$. longula also showed a high number of infective propagules and promoted biomass accumulation in maize plants. The system of inoculum production using sand and vermiculite $+10 \%$ vermicompost favors the production of infective inoculum of $A$. longula with the fungus benefiting growth of corn plants.
\end{abstract}

Key words: AMF, biofertilizer, vermicomposto, inoculum.

\section{Introduction}

Many studies have described the importance of arbuscular mycorrhizal fungi (AMF) for agriculture as well as for reforestation programs of degraded areas (Caravaca et al., 2002; Douds Jr et al., 2007; Ijdo et al., 2011; Jarstfer and Sylvia, 1992; Souza et al., 2010). Brazil offers a great potential for use of this biotechnological tool (Souza et al., 2006); however, one of the obstacles for the application of AMF and the large-scale production of mycorrhizal inoculum is the obligate biotrophy of these fungi.

Various methods have been tested for the production of mycorrhizal inoculum, such as: aeroponics, hydroponics, in vitro cultivation, "pot cultures" and on-farm (Ijdo et al., 2011). Traditionally these fungi are multiplied in "pot cultures", in association with roots of a host plant in a determined substrate (Gaur and Varma, 2007).
The chosen substrate for the cultivation of AMF can directly influence the production and the infectivity of the inoculum (Baby and Manibhushanrao, 1996; Jayaratne and Siriwardene, 2011), and should contain minimal nutrients to guarantee the survival of the host plant so that the fungus can sporulate and multiply (Jarstfer and Sylvia 1992; Silva et al., 2005).

A promising system is the use of sand and vermiculite, which favors the production of glomerospores with increased infectivity (Silva et al., 2005; Silva et al., 2007). However, the addition of nutrient solution to the substrate is a barrier to the system because it is not simple and economical (Gianinazzi and Vosátka, 2004). The use of organic sources and the efficiency of the produced isolates are important aspects to define the quality of the inoculums (Singh et al., 2011). The infectivity can be estimated by observing fungal structures in the root with various tech- 
niques that will indicate the viability of the inoculum (Feldmann and Idczak, 1994; INVAM, 2010). However, the efficiency of the isolates is not always related to the degree of mycorrhizal colonization (Corkidi et al., 2004), making it necessary to test the effectiveness of the inoculum as well.

Large-scale production of infective and efficient AMF inoculum using low-cost and easily accessible materials continues being a necessity to make viable the application of these fungi in agriculture and for environmental recovering programs. The objective of this study was to select organic substrates that maximize the production of mycorrhizal inoculum of high quality.

\section{Materials and Methods}

Three experiments were carried out: in the first, an organic substrate to produce AMF inoculum was selected; in the second, the infectivity of the inoculum that in the previous experiment produced more spores was determined; in the third, the efficiency of this inoculum to increase the growth of corn plants was evaluated. All the experiments were carried out in a greenhouse at the University of Pernambuco, PE. The initial inocula were produced in organic substrates (topsoil and organic compost), using folder millet (Panicum miliaceum L) as the host plant and stored at $4{ }^{\circ} \mathrm{C}$ until being used (Silva, 2006).

\section{Experiment 1 - Selection of organic substrates for the production of mycorrhizal inoculum}

Four substrates to produce AMF inoculum were tested together with sand and vermiculite $(1: 1 \mathrm{v} / \mathrm{v})$ : (a) nutritive solution $=$ control; (b) $10 \%$ of vermicompost; (c) $10 \%$ of coir dust, (d) $10 \%$ of Tropstrato ${ }^{\circledR}$, a commercial substrate compound of vermiculite, vegetable coal and pinus chip. The sand, from river, was washed and, just as the vermiculite, sterilized in autoclave $\left(120^{\circ} \mathrm{C}, 30 \mathrm{~min}\right)$ for two consecutive days. After preparing the mixtures of substrate, samples from each one of them were taken for chemical and physical analysis at Embrapa Semi-Árido (Table 1). For the experiments the substrates were placed in pots of $400 \mathrm{~mL}$ capacity. The organic substrates were commercially acquired and are widely used in agriculture.

Folder millet was used as host. The seeds were disinfected $(0.5 \%$ sodium hypochlorite for $3 \mathrm{~min})$ and washed with distilled water.

Four AMF isolates were tested: Acaulospora longula Spain \& Schenck (UFPE 21), Claroideoglomus etunicatum (W.N. Becker \& Gerd.) C. Walker \& A. Schüßler (UFPE 06), Dentiscutata heterogama (T.H. Nicolson \& Gerd.) Sieverd., F.A. Souza \& Oehl (UFPE 19) and Gigaspora albida Schenck \& Smith (UFPE 01).

For each pot suspensions containing 100 spores of each AMF isolate were deposited under 50 folder millet seeds and the pots were kept at the greenhouse $\left(28{ }^{\circ} \mathrm{C}\right.$ $\pm 2{ }^{\circ} \mathrm{C}$ ) for 60 days. All pots were irrigated every two days; the control treatment received a nutrient solution, modified by Jarstfer and Sylvia (1992) and supplemented with Tris$\mathrm{HCl}$ (Silva et al., 2005) while the other treatments were irrigated with distilled water.

For each AMF isolate the experimental design was completely randomized with four substrate treatments and five replicates (80 experimental units).

The AMF spores were extracted from the substrates by wet sieving (Gerdemann and Nicolson, 1963) and water

Table 1 - Physical and chemical characterization of the substrates used to produce AMF inoculum

\begin{tabular}{|c|c|c|c|c|}
\hline \multirow[t]{2}{*}{ Characteristics } & \multicolumn{4}{|c|}{ Substrates (base: sand + vermiculite) } \\
\hline & Base & $+10 \%$ of vermicompost & $+10 \%$ of coir dust & $+10 \%$ of Tropstrato ${ }^{\circledR}$ \\
\hline $\mathrm{OM}(\mathrm{g} / \mathrm{kg})$ & 0.72 & 3.10 & 5.59 & 7.45 \\
\hline $\mathrm{P}\left(\mathrm{mg} / \mathrm{dm}^{3}\right)$ & 17.85 & 61.50 & 30.45 & 50.78 \\
\hline $\mathrm{pH}\left(\mathrm{H}_{2} \mathrm{O}-1: 2.5\right)$ & 6.30 & 6.80 & 6.90 & 6.20 \\
\hline $\mathrm{CEC}\left(\mathrm{cmol} / \mathrm{dm}^{3}\right)$ & 6.41 & 7.39 & 6.37 & 6.71 \\
\hline $\mathrm{K}\left(\mathrm{cmol} / \mathrm{dm}^{3}\right)$ & 0.17 & 0.36 & 0.38 & 0.23 \\
\hline $\mathrm{Fe}\left(\mathrm{cmol} / \mathrm{dm}^{3}\right)$ & 46.30 & 31.80 & 44.30 & 49.60 \\
\hline $\mathrm{Zn}\left(\mathrm{cmol} / \mathrm{dm}^{3}\right)$ & 1.00 & 3.80 & 1.30 & 1.60 \\
\hline $\mathrm{Na}\left(\mathrm{cmol} / \mathrm{dm}^{3}\right)$ & 0.25 & 0.44 & 0.23 & 0.33 \\
\hline Total sand (g/kg) & 957.82 & 942.76 & 963.20 & 950.80 \\
\hline Silt $(g / k g)$ & 22.27 & 54.84 & 35.31 & 42.65 \\
\hline Clay (g/kg) & 19.91 & 2.41 & 1.49 & 6.55 \\
\hline Porosity $(\%)$ & 41.02 & 40.47 & 41.94 & 39.92 \\
\hline Apparent density $\left(\mathrm{km} / \mathrm{dm}^{3}\right)$ & 1.51 & 1.53 & 1.44 & 1.49 \\
\hline Real density $\left(\mathrm{km} / \mathrm{dm}^{3}\right)$ & 2.56 & 2.57 & 2.48 & 2.48 \\
\hline
\end{tabular}

$\mathrm{OM}=$ organic matter; $\mathrm{CEC}=$ cation-exchange capacity. 
and sucrose centrifugation (Jenkins 1964), and quantified in a stereomicroscope (40x).

The number of spores was transformed to $\log \mathrm{x}+1$, submitted to ANOVA and the means compared by the Tukey test (5\%), using the Statistica program (Statsoft, 1997).

\section{Experiment 2 - Infectivity of the mycorrhizal inoculum produced in substrates with organic fertilizer}

Samples of the inoculum of $A$. longula, C. etunicatum, D. heterogama and G. albida multiplied in substrate with $10 \%$ vermicompost were used immediately after being produced. This inoculum was selected in the previous experiment and produced more spores than the other treatments. To evaluate the infectivity of this inoculum, two methods were used:

A) NMP = samples of the inoculum consisting of spores, colonized hyphae and roots were diluted $(1: 10$; 1:100: $1: 1000 \mathrm{v} / \mathrm{v})$ with autoclaved sand $\left(121^{\circ} \mathrm{C}, 1 \mathrm{~h}\right)$ using corn seeds disinfected (Zea mays L. cv. Assum Preto) as host plant. After 30 days in the greenhouse, the plants were harvested and the roots washed, clarified with $10 \% \mathrm{KOH}$, stained with Trypan blue $(0.05 \%)$ (Phillips and Hayman, 1970), and the presence of mycorrhizal structures observed to estimate the most probable number (MPN) of infective propagules using the Cochran's table (Feldmann and Idczak, 1994).

B) $\mathrm{MIP}=$ The mean percentage of infection (INVAM, 2010) of the inoculum was evaluated in roots cultivated in the dilution 1:10 (inoculum:disinfested sand) (experiment 2A) with the colonization determined by the gridline intersect method (Giovannetti and Mosse, 1980).

\section{Experiment 3 - Effectiveness of AMF multiplied in substrates with organic fertilizer}

The soil used in this trial was collected in an area of native Caatinga close to $\mathrm{km} 152$, in the municipality of Petrolina-PE, and taken for chemical analysis at the Embrapa Semi-Arido, presenting the following characteristics: $3 \mathrm{mg} \mathrm{dm}{ }^{-3}$ of $\mathrm{P} ; 2.48 \mathrm{~g} \mathrm{~kg}^{-1}$ of organic matter; $9.62 \mathrm{cmol} \mathrm{dm}^{-3}$ of cation-exchange capacity and $\mathrm{pH}$ 4.9. Pots with a $2 \mathrm{~L}$ capacity were used for the experiment.

Corn seeds were disinfected with $0.5 \%$ sodium hypochlorite for three minutes and washed with distilled water. Inocula (10 mL) of G. albida, A. longula, C. etunicatum e D. heterogama, multiplied in sand and vermiculite $+10 \%$ vermicompost, obtained from experiment 1 were separately placed below four corn seeds in pots of $2 \mathrm{~L}$ capacity. After germination, thinning was carried out, leaving only one plant per pot. The pots were kept in the greenhouse and irrigated every other day with filtered water.

Seventy days after inoculation fresh and dry matter of the aerial part and the total fresh and dry matter of the plants were evaluated. The dry matter was determined after leav- ing the plants in an oven $\left(40{ }^{\circ} \mathrm{C}\right)$ until constant weight. The growth increase was calculated based on the total dry biomass (Weber et al., 2004).

The biomass data were submitted to ANOVA and the means compared by the Tukey test $(5 \%)$, using the Statistica program (Statsoft, 1997).

\section{Results and Discussion}

In the first experiment the organic substrates affected AMF spores production $(\mathrm{p}<0.05)$. The addition of these substrates favored sporulation, but the benefits depended on the organic source added to the basic substrate (Table 2).

The vermicompost added to sand + vermiculite promoted higher sporulation of $A$. longula in relation to the other AMF and substrates. The Tropstrato ${ }^{\circledR}$ inhibited the sporulation of $D$. heterogama while the reproduction of C. etunicatum was not affected by the organic compounds. These results confirm that some species benefit more than others from organic fertilization (Silva 2006). Oehl et al. (2004) reported a high abundance of Acaulosporaceae species and a low frequency of occurrence of Gigaspora and Scutellospora species in areas with organic fertilization. The sporulation of the isolate of C. etunicatum did not differ in terms of substrate; this was probably due to the functional plasticity of the species (Weissenhorn et al., 1994).

Organic sources applied to the soil can increase production of AMF (Douds Jr et al., 2006; Gaur and Adholeya, 2005) and the addition of these residues to the medium used to produce inoculum increases sporulation (Silva et al., 2005), as registered in this study (Table 2). Baby and Manibhushanrao (1996) tested 12 organic sources and reported that the type of organic source influences the production of spores, because some substances present in the organic compost can have a phytotoxic effect and/or inhibit the development of AMF (Martín et al., 2002).

The nutrient solution used in the basic substrate can be substituted by organic sources, and depending on the AMF isolate and the type of organic source used, the production of spores can increase in relation to the use of the solution. Sporulation of A. longula increased $2420 \%$ when

Table 2 - Production of AMF spores (GA- Gigaspora albida; CEClaroideoglomus etunicatum; AL- Acaulospora longula; DHDentiscutata heterogama) in substrates with a sand and vermiculite basis to which organic substrates were added, using proso millet as host, 60 days after inoculation under protective cropping.

\begin{tabular}{lcccc}
\hline \multirow{2}{*}{ Substrates } & \multicolumn{4}{c}{ AMF (spores/20 mL) } \\
\cline { 2 - 5 } & GA & CE & AL & DH \\
\hline Control & $9.4 \mathrm{ab}$ & $6.4 \mathrm{a}$ & $7.8 \mathrm{bc}$ & $8.2 \mathrm{a}$ \\
Tropstrato $^{\circledR}$ & $4.2 \mathrm{~b}$ & $4.2 \mathrm{a}$ & $2.8 \mathrm{c}$ & $2.2 \mathrm{~b}$ \\
Coir dust & $4.6 \mathrm{~b}$ & $3.0 \mathrm{a}$ & $9.4 \mathrm{~b}$ & $5.2 \mathrm{ab}$ \\
Vermicompost & $45.4 \mathrm{a}$ & $8.8 \mathrm{a}$ & $196.6 \mathrm{a}$ & $6.8 \mathrm{a}$ \\
\hline
\end{tabular}

Means followed by the same letter do not differ by the Tukey test $(5 \%)$. 
the isolate was maintained in the substrate with vermicompost in relation to the control. This increase is probably due to the soil cation-exchange capacity and to the nutrients present in the vermicompost (Table 1). The soil properties benefit from the use of vermicompost (Cavender et al., 2003), favoring the availability of nutrients in relation to other organic sources (Samaranayake and Wijekoon, 2010). These data are in accordance with those obtained by Silva (2006) when using organic sources to produce mycorrhizal inoculum.

The greatest spore production was observed in substrates with $10 \%$ vermicompost. Possibly, the value of $\mathrm{P}$ affected the outcome since this nutrient plays an important role in the regulation of production of AMF propagules (Posada et al., 2008). However, Douds Jr (1994) observed that the addition of $\mathrm{P}$ to the solution used to irrigate diminished the production of spores. It is likely that the isolates multiplied in the present study were more adapted to the conditions of high fertilization (especially P) once they were produced in organic substrate with high P-levels (Silva, 2006).

The negative effect of Tropstrato ${ }^{\circledR}$ on sporulation of $D$. heterogama was possibly due to the chemical composition of the substrate, with high levels of Mn, Ca and Fe (Table 1). High concentrations of $\mathrm{Mn}$ and Fe in the substrate can inhibit the germination of spores and mycelial growth (Moreira and Siqueira 2002). Cardoso et al. (2002) observed that an isolate of $D$. heterogama was more tolerant than others in relation to the $\mathrm{Mn}$ doses tested. The Ca can interfere in the permeability of the membranes and consequently in the colonization of the roots (Moreira and Siqueira, 2002).

Besides the composition, the granulometry of the medium can influence the production of propagules; however, the substrates used in this study did not show a significant granulometric difference (Table 2). Gaur and Adholeya (2000) observed that there was more sporulation of AMF in soil with $0.78-0.50 \mathrm{~mm}$ particles and a greater weight of the roots in relation to soils with other particle sizes. However, a mixture of materials with particles of different sizes also stimulated sporulation in relation to other mixtures (Verma et al., 2008). The use of organic substrates is advantageous because it reduces the apparent density and increases the porosity (Caravaca et al., 2002). The decrease in the density of the material is also pointed out as one of the objectives to produce low cost inoculum for commercial purposes (Jayaratne and Siriwardene, 2000; Silva, 2006). In the present study, the addition of organic sources did not cause any significant differences in the density or porosity; thus, in this case spore production was not determined by the physical characteristics of the substrates.

Considering the tested isolates, the high percentage of colonization and the low number of infective propagules of G. albida can be the result of the biology of the fungus. Spores of Gigaspora species may produce many germ tubes, establishing in this way various possibilities for colonization of the host (Maia et al., 1993). In general, members of the Gigasporaceae family produce few spores (Souza et $a l ., 2005)$ and are incapable of colonizing from hyphae fragments (Klironomos and Hart, 2002), as happens with Acaulospora (Hart and Reader, 2002). However, it has been shown that G. albida can have a greater infective capability than A. longula (Silva et al., 2005).

The inoculum of $A$. longula produced a high number of infective propagules, although spores of this species are known to have a long dormancy period (Tommerup, 1983); it is possible that the hyphae play a more important role than the spores in the colonization process (Silva et al., 2005). The colonization produced by the AMF was not related with the number of infective propagules (Table 3), as also mentioned by Sreenivasa and Bagyaraj (1988).

Some commercialized inocula show 19 to $54 \%$ of colonization rate, as evaluated by the MIP (INVAM 2011). Considering the colonization produced by the tested inocula, which was within the suggested range for commercial inoculum they can therefore be recommended for use as biofertilizers.

With the exception of G. albida $( \pm)$ the produced inocula incremented the production of biomass of the corn plants. The capacity of the introduced AMF being more efficient can be due to the low activity of native AMF (Douds Jr et al., 2007), as observed in the control treatment. Another factor that may have contributed to the results of this study was the interaction of the fungal isolate with the plant species (Hart and Reader, 2002; Pouyu-Rojas et al., 2006). Growth of corn plants was not increased by inoculation with G. albida; it is possible that this isolate, under the experimental conditions, consumed more Carbon from the host than that available just for the fungus (Klironomos et al., 2000).

The inoculum of $A$. longula was effective in stimulating biomass accumulation in corn plants (Table 4). In other situations, inoculation with isolates of $A$. longula was beneficial to seedlings of soursop (Annona muricata) (Silva et al., 2008), leucaena (Leucaena leucocephala) (Lins et al., 2007) and native plants used for revegetation (Souza et al., 2010).

Table 3 - Number of infective propagules in the inocula produced in substrates with a basis of sand and vermiculite to which $10 \%$ of vermicompost was added and mycorrhizal colonization in corn roots, 30 days after inoculation.

\begin{tabular}{lcc}
\hline Isolates & $\begin{array}{c}\mathrm{N}^{\mathrm{o}} \text { of propagules } \\
\left(\mathrm{cm}^{-3} \text { substrate) }\right.\end{array}$ & $\begin{array}{c}\text { Mycorrhizal } \\
\text { colonization (\%) }\end{array}$ \\
\hline Acaulospora longula & $>1600$ & 23.2 \\
Gigaspora albida & 180 & 56.9 \\
Claroideoglomus etunicatum & 350 & 31.8 \\
Dentiscutata heterogama & 32 & 19.8 \\
\hline
\end{tabular}


Table 4 - Fresh and dry matter of corn plants (Zea mays) cultivated in native Caatinga soil, inoculated with $10 \mathrm{~mL}$ of soil-inoculum, and maintained in greenhouse for 70 days.

\begin{tabular}{lccc}
\hline Isolates & $\begin{array}{c}\text { Fresh matter } \\
(\mathrm{g})\end{array}$ & $\begin{array}{c}\text { Dry matter } \\
(\mathrm{g})\end{array}$ & $\begin{array}{c}\text { Increment } \\
(\%)\end{array}$ \\
\hline Control & $4.47 \mathrm{~b}$ & $0.70 \mathrm{bc}$ & - \\
Acaulospora longula & $8.62 \mathrm{a}$ & $2.44 \mathrm{ab}$ & 92.8 \\
Gigaspora albida & $3.52 \mathrm{~b}$ & $1.22 \mathrm{c}$ & -21.2 \\
Claroideoglomus etunicatum & $8.90 \mathrm{a}$ & $2.67 \mathrm{a}$ & 99.1 \\
Dentiscutata heterogama & $7.31 \mathrm{ab}$ & $1.94 \mathrm{abc}$ & 63.5 \\
\hline
\end{tabular}

Means followed by the same letter, in the column, do not differ by the Tukey test (5\%).

Inoculum produced in substrates with organic fertilizer can benefit the host in a differentiated way. Douds et al. (2008) observed that the inoculum produced with organic sources promoted better growth of potato seedlings in relation to uninoculated plants maintained in native soil. Conversely, Silva et al. (2008) observed that inoculum of A. longula produced in soil promoted more growth of soursop then inoculum produced in soil $+10 \%$ of vermicompost; however, the same was not observed for G. albida.

A system for inoculum production has quality when, besides stimulating sporulation, it provides high infectivity and efficiency (Gianinazzi and Vosátka, 2004). Thus, from the tested isolates, only $A$. longula presented such characteristics, when multiplied in substrate with vermicompost. It is important to emphasize that the sporulation of this fungus was lower than that registered in other studies (Silva et al., 2005; Silva et al., 2007; Zambolim et al., 1992) but the fungus was infective and effective in favoring growth of corn.

The results suggest that the production of inoculum using sand and vermiculite $+10 \%$ vermicompost favours the reproduction of $A$. longula with the fungus being beneficial to the host.

\section{Conclusions}

In the system of inoculum production using sand and vermiculite, the substitution of nutrient solution by organic fertilizers can improve sporulation, but the benefits vary according to the fungus and the organic source.

The substrate on the basis of sand and vermiculite $+10 \%$ of vermicompost favors the production of inoculum of $C$. etunicatum infective and effective in increasing the biomass of corn.

Reproduction of $A$. longula can be improved in sand and vermiculite $+10 \%$ of vermicompost and the inoculum is infective and effective immediately after being produced.

\section{References}

Baby UI, Manibhushanrao K (1996) Influence of organic amendments on arbuscular mycorrhizal fungi in relation to rice sheath blight disease. Mycorrhiza 6:201-206.

Caravaca F, Barea J.M, Figueroa D, Roldán A (2002) Assessing the effectiveness of mycorrhizal inoculation and soil compost addition for enhancing reforestation with Olea europaea subsp. Sylvestris through changes in soil biological and physical parameters. Appl. Soil Ecol 20:107-118.

Cardoso EJBN, Navarro RB, Nogueira MA (2002) Manganês e germinação de esporos de fungos micorrízicos arbusculares in vitro. $\mathrm{R}$ Bras Ci Solo 26:795-799.

Cavender ND, Atiyeh RH, Knee M (2003) Vermicompost stimulates mycorrhizal colonization of roots of Sorghum bicolor at the expense of plant growth. Pedobiologia 47:85-89.

Corkidi L, Allen EB, Merhaut D, Allen MF, Downer J, Bohn J, Evans M (2004) Assessing the infectivity of commercial mycorrhizal inoculants in plant nursery conditions. J Environ Hortic 22:149-154.

Douds Jr DD (1994) Relationship between hyphal and arbuscular colonization and sporulation in a mycorrhizal of Paspalum notatum Flugge. New Phytol 126:233-237.

Douds Jr DD, Nagahashi G, Pfeffer PE, Reider C, Kayser WM (2006) On-farm production of AM fungus inoculum in mixture of compost and vermiculite. Bioresour Technol 97:809-818.

Douds Jr DD, Nagahashi G, Reider C, Hepperly PR (2007) Inoculation with arbuscular mycorrhizal fungi increases the yield of potatoes in a high P soil. Biol Agric Hortic 25:67-78.

Feldmann F, Idczak E (1994) Inoculum production of vesicular-arbuscular mycorrhizal fungi for use in tropical nurseries. In: Norris JR, Read D, Varma AK (eds) Techniques for Mycorrhizal Research Methods in Microbiology. Academic Press, London, pp 799-833.

Gaur A, Adholeya A (2000) Effects of the particle size of soilless substrates upon AM fungus inoculum production. Mycorrhiza 10:43-48.

Gaur A, Adholeya A (2005) Diverse response of five ornamental plant species to mixed indigenous and single isolate arbuscular mycorrhizal inocula in marginal soil amendment with organic matter. J Plant Nutr 28:707-723.

Gaur A, Varma A (2007) Research methods in arbuscular mycorrhizal fungi. In: Varma A, Oelmüller R (eds) Soil biology: Advanced Techniques in Soil Microbiology. Springer, New York, pp 377-396.

Gerdemann JW, Nicolson TH (1963) Spores of mycorrhizal Endogone species extracted from soil by wet sieving and decanting. Trans Br Mycol Soc 46:235-244.

Gianinazzi S, Vosátka M (2004) Inoculum of arbuscular mycorrhizal fungi for production systems: science meets business. Can J Bot 82:1264-1271.

Giovannetti M, Mosse B (1980) An evaluation of techniques for measuring vesicular arbuscular mycorrhizal infection in roots. New Phytol 84:489-500.

Hart MM, Reader RJ (2002) Host plant benefit from association with arbuscular mycorrhizal fungi: variation due to differences in size of mycelium. Biol Fertil Soils 36:357-366.

Ijdo M, Cranenbrouck S, Declerck S (2011) Methods for largescale production of AM fungi: past, present, and future. Mycorrhiza 21:1-16. 
INVAM 2010. Mean infection percentage (MIP) method. Available at: http://invam.caf.wvu.edu/Myc-Info/Methods/assays/MIP.htm. Accessed 16 May 2010.

INVAM 2011. Results of infectivity (MIP) assays of commercial Inoculants. Available at: http://invam.caf.wvu.edu/otherinfo/commercial/commercial_MIPs.pdf. Accessed 29 December 2011.

Jarstfer AG, Sylvia DM (1992) Inoculum production and inoculation strategies for vesicular-arbuscular mycorrhizal fungi. In: Dekker MBM (ed) Soil Microbial Tecnologies: Applications in Agriculture, Forestry and Environmental Management. Marcel Dekker, New York, pp 349-377.

Jayaratne AHR, Siriwardene D (2000) Arbuscular mycorrhizal inoculum production for commercial use. Trop Agric Res Ext 3:137-140.

Jenkins WR (1964) A rapid centrifugal-flotation technique for separating nematodes from soil. Pl Dis Rep 48:692.

Klironomos JN, Hart MM (2002) Colonization of roots by arbuscular mycorhizal fungi using different souces of inoculum. Mycorrhiza 12:181-184.

Klironomos JN, Mccune J, Hart M, Neville J (2000) The influence of arbuscular mycorrhizae on the relationship between plant diversity and productivity. Ecol Lett 3:137-141.

Lins CEL, Maia LC, Cavalcante UMT, Sampaio EVSB (2007) Efeito de fungos micorrízicos arbusculares no crescimento de mudas de Leucaena leucocephala (LAM.) de Wit. em solos de Caatinga sob impacto de mineração de Cobre. Rev Árvore 31:355-363.

Maia LC, Kimbrough JW, Benny GL (1993) Ultrastructural studies of the spore wall of Gigaspora albida (Glomales). Mycologia 85:883-889.

Martín J, Sampedro I, García-Romera I, Gárcia-Garrido JM, Ocampo JA (2002) Arbuscular mycorrhizal colonization and growth of soybean (Glycine max) and lettuce (Lactuca sativa) and phytotoxic effects of olive mill residues. Soil Biol Biochem 34:1769-1775.

Moreira FMS, Siqueira JO (2002) Micorrizas. In: Moreira FMS, Siqueira JO (eds) Microbiologia e Bioquímica do Solo. UFLA, Lavras, pp 473-539.

Oehl F, Sieverding E, Mader P, Dubois D, Ineichen K, Boller T, Weimken A (2004) Impact of long-term conventional and organic farming on the diversity of arbuscular mycorrhizal fungi. Oecologia 138:574-583.

Phillips JM, Hayman DS (1970) Improved procedures for clearing roots and staining parasitic and vesicular arbuscular mycorrhizal fungi for rapid assessment of infection. Trans $\mathrm{Br}$ Mycol Soc 55:157-161.

Posada RH, Franco LA, Ramos C, Plazas LS, Suárez JC, Álvarez F (2008) Effect of physical, chemical and environmental characteristics on arbuscular mycorrhizal fungi in Brachiaria decumbens (Stapf) pasture. J Appl Microbiol 104:132-140.

Pouyu-Rojas E, Siqueira JO, Santos JGD (2006) Compatibilidade simbiótica de fungos micorrízicos arbusculares com espécies arbóreas tropicais. R Bras Ci Solo 30:413-424.
Samaranayake JWK, Wijekoon S (2010) Effect of selected earthworms on soil fertility, plant growth and vermicomposting. Trop Agric Res Ext 13:33-40.

Silva DKA, Silva FSB, Yano-Melo AM, Maia LC (2008) Uso de vermicomposto favorece o crescimento de mudas de gravioleira (Annona muricata L. 'Muricata') associada a fungos micorrízicos arbusculares. Acta Bot Bras 22:863-869.

Silva FSB (2006) Fase assimbiótica, produção, infectividade e efetividade de fungos micorrízicos em substratos com adubos orgânicos. PhD Thesis, Centro de Ciências Biológicas, Recife, 297 pp.

Silva FSB, Yano-Melo AM, Brandão JAC, Maia LC (2005) Sporulation of arbuscular mycorrhizal fungi using Tris- $\mathrm{HCl}$ buffer in addition to nutrient solutions. Braz J Microbiol 36:327-332.

Silva FSB, Yano-Melo AM, Maia LC (2007) Production and infectivity of inoculum of arbuscular mycorrhizal fungi multiplied in a substrate supplemented with Tris- $\mathrm{HCl}$ buffer. Braz J Microbiol 38:752-755.

Singh R, Divya S, Awasthi A, Kalra A (2011) Technology for efficient and successful delivery of vermicompost colonized bioinoculants in Pogostemon cablin (patchouli) Benth. World J Microbiol Biotechnol 28:323-333.

Souza FA, Dalpé Y, Declerck S, La Providencia IE, SéjalonDelmas N (2005) Life history strategies in Gigasporaceae: Insight from monoxenic culture. In: Declerck $\mathrm{S}$, Strullu D-G, Fortin JA (eds) Soil Biology - In Vitro Culture of Mycorrhyzas. Springer, New York, pp 73-91.

Souza RG, Goto BT, Silva DKA, Silva FSB, Sampaio EVSB, Maia LC (2010) The role of arbuscular mycorrhizal fungi and cattle manure in the establishment of Tocoyena selloana Schum. in mined dune areas. Eur J Soil Biol 46:237-242.

Souza VC, Silva RA, Cardoso GD, Barreto AF (2006) Estudo sobre fungos micorrízicos. Rev Bras Eng Agric Ambient 10:612-618.

Sreenivasa MN, Bagyaraj DJ (1988) Selection of a suitable substrate for mass multiplication of Glomus fasciculatum. Plant Soil 109:125-127.

Statsoft (1997) Inc, Statistica for Windows (Computer Program Manual). Tulsa, USA

Tommerup IC (1983) Spore dormancy in vesicular-arbuscular mycorrhizal fungi. Trans Br Mycol Soc 81:37-45.

Verma N, Chaturvedi S, Sharma AK (2008) Mass multiplication of AMF using soilless substrates. Mycorrhiza News 20:11-15.

Weber OB, Souza CM, Gondin DF, Oliveira FNS, Crisóstomo LA, Caproni AL, Saggin Jr O (2004) Inoculação de fungos micorrízicos arbusculares e adubação fosfatada em mudas de cajueiro-anão-precoce. Pesq Agropec Bras 39:477-483.

Weissenhorn I, Glashoff A, Leyval C, Berthelin B (1994) Differential tolerance to $\mathrm{Cd}$ and $\mathrm{Zn}$ of arbuscular mycorrhizal (AM) fungal spores isolated from heavy metal-polluted and unpolluted soil. Plant Soil 167:189-196.

Zambolim L, Reis MA, Costa LM (1992) Substratos para a multiplicação de inóculo do fungo micorrízico vesículo-arbuscular Glomus etunicatum. Fitopatol Bras 17:28-31.

All the content of the journal, except where otherwise noted, is licensed under a Creative Commons License CC BY-NC. 